\title{
Analisis Produk Tabungan Mudhorobah Berjangka Di Bmt Tanjung
}

\author{
Firdausiah $^{1}$, \\ ${ }^{1}$ Universitas Nurul Jadid \\ Email: firdausiah@gmail.com ${ }^{1}$,
}

\begin{abstract}
Abstrak
Penelitian ini menganalisis tentang tabungan mudhorobah berjangka di BMT Tanjung. BMT Tanjung merupakan pusat penghimpun dan penyalur dana yang dipercaya oleh masyarakat sekitar, BMT memiliki beragam jenis produk syariah yang dijalakan dalam kegiatan prakteknya salah satunya adalah produk tabungan berjangka syariah, yang menerapkan akad mudorobah dimana nasabah akan mendapatkan keuntungan yang disepakati diawal. Dalam hal ini BMT menjalankan produk tersebut dirasa menguntungkan kedua belah pihak. Oleh karena itu penulis sangat tertarik mengangkat judul "analisis produk tabungan mudhorobah berjangka di BMT Tanjung." BMT tanjung menghasilkan produk tabungan mudhorobah berjangka yang diperoleh dari ijtihad baru yang dikonsep dan dikreasikan sedemikian rupa hingga menjadi produk unik yang berbeda produk tabungan pada umumnya. Keunikan produk ini terletak pada pola bagi hasil yang diberlakukan yaitu mengganti bagi hasil dengan cara pemberian hadiah langsung yang dilakukan setiap satu tahun sekali di akhir bulan. Penelitian ini berjenis kualitatif data yang dibutuhkan digali dengan cara melakukan fiel research kelokasi penenelitian secara langsung. Hasil penelitian menyimpulkan bahwa jika produk tabungan mudhorobah berjangka BMT Tanjung sudah secara aplikasi sesuai dengan hukum syariah yang ada dan dapat diterima oleh kalangan masyarakat sekitar.
\end{abstract}

Kata Kunci: Tabungan berjangka, bagi hasil, Produk mudhorobah 


\section{PENDAHULUAN}

Keberadaan bank syariah belum begitu merakyat, hal ini dapat dilihat dari sedikitnya bank syariah yang ada dibandingkan bank konvesional. BMT sebagai salah satu lembaga keuangan yang bertugas menghimpun dana dan menyalurkan pada masyarakat (Kasmir, 2005). Dari segi pelayanan pun keberadaannya tidak mampu menjangkau usaha mikro ini dikarenakan usaha tersebut tidak memenuhi prosedur perbankan yang dibakukan UU (Muhammad, 2004). Ketidak mampuan tersebut menjadi salah satu penyebab kekosongan segmen pasar keuangan diwilayah pedesaan,keadaan ini memungkinkan rentenir dan juga lembaga berbasis bunga lain untuk memasukinya. Oleh karena itu diperlukan lembaga unit keuangan syariah alternatif yang tidak melakukan pemusatan kekayaan kepada sebagian pemilik modal, yang dapat membangun kebersamaan untuk mencapai kemakmuran bersama seperti BMT(Baitul Maal Wat Tamwil).

Baitul Maal Wat Tamwil (BMT) merupakan bagian dari Bank Syariah atau semacam LSM yang beroperasi seperti bank koperasi dengan pengecualiannya yang kecil serta tidak mempunyai akses ke pasar ruang.Baitul Maal wat Tamwil terdiri dari dua macam jenis istilah yaitu Baitul Maal dan Baitul Tamwil (Sudarsono, 2003). Baitul Maal adalah lembaga keuangan umat Islam yangmengelola dana umat Islam yang bersifat sosial dan sumber dana BaitulMaal berasal dari Zakat, Infaq, Sodaqoh, Hibah dan lain-lain. SedangkanBaitul Tamwil adalah lembaga keuangan yang mengelola dana umat yangsesuai dengan syariat Islam.Sebuah tempat yang biasa digunakan untuk menyimpan danamasyarakat adalah sebuah lembaga keuangan syariah, lembaga keuangansyariah tersebut bisa berupa bank maupun non-bank. Salah satu contohlembaga keuangan syariah yang berbentuk non-bank adalah Baitul Maal Wattamwil (BMT). Baitul Maal Wattamwil (BMT) yang fungsinyamenghimpun dan menyalurkan dana masyarakat, saat ini keberadaanya sudah membantu mengentaskan kemiskinan dan membantu pertumbuhan mikro menengah. Sebagai contoh, BMT yang sudah melaksanakan visidan misinya dengan baik adalah BMT Tanjung.

Fungsi utama dari BTM Tanjung adalah sebagai lembaga intermediary yaitu sebagai lembaga yang menyalurkan dana dari pihak yang mengeluarkan dana pada pihak yang memerlukanya. Apabila pemanfaatan dilakukan dengan optimal, amanah dan profesional, maka roda perekomomian masyarakat akan sejahtera, dikarena dana dari pihak yang mengeluarkan dana akan dimanfaatkan oleh pihak yang memerlukan dana dengan tujuan produksi, investasi, ataupun konsumsi.

Produk penghimpunan dana di BMT terdiri dari berbagai macam jenisnya, yang salah satunya produk penghimpunan dana BMT Tanjung adalah produk tabungan syariah yang disebut Tabungan Berjangka dengan jangka waktu tertentu. Tabungan Berjangka merupakan investasi masa depan yang penarikanya hanya dapat dilakukan dalam jangka waktu tertentu (jatuh tempo) dengan mendapa timbalan bagi hasil menurut kesepakatan bersama. Dalam pelaksanan produk tersebut menggunakan akad mudharabah, yaitu salah satu bentuk kerjasama antara pemilik modal dan pedagang/pengusaha/orang yang mempunyai keahlian untuk melakukan sebuah usaha bersama.

Mekanisme yang digunakan oleh BMT Tanjung untuk bagi hasil adalah tabungan berjangka syariah karena tabungan serta penarikan hanya dapat dilakukan pada waktu waktu tertentu meneurut perjanjian antara nasabah dan lembaga yang bersangkutan. 
Volume 02 Nomor 022020 : page 81-95 p-ISSN: 2686-262X e-ISSN : 2685-9300 DOI : 10.24256

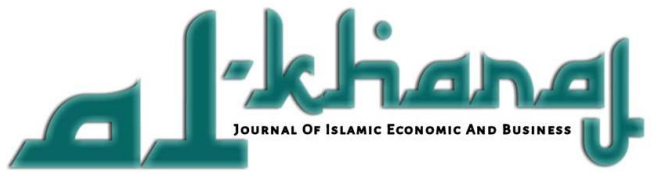

Sedangkan Peranan umum Baitul Maal Tamwil (BMT) adalah melakukan pembinaan dari pendanaan pada usaha-usaha yang dilakukan oleh masyarakat menegah kebawah dengan berdasarkan sistem perekonomian syari'ah Islam. Untuk menjaga peranannya tersebut, maka dibuat produk penyaluran dana yang salah satunya adalah tabungan berjangka,dengan menggunakan syari'ah Islam. Produk tabungan berjangka ini dirancang sebagai sarana investasi jangka panjang yang aman selain itu nasabah tentunya dapat membantu menjadi penyedia modal yang dananya dikelola dan diinvestasikan terhadap usaha-usaha syari'ah yang dibiayai oleh BMT. BMT Tanjung menggunakan akad Mudharabahkarena dirasa akan menguntungkan kedua belah pihak yaitu pemilik modal(shahibul maal) dan pengelola dana (mudharib). Akad yang sesuai dengan prinsip investasi adalah mudharabbah yang mempunyai tujuan kerjasama antara pemilik dana (shahibul maal) dan pengelola dana (mudharib), pihak yang bersangkutan adalah bank. Pemilik dana sebagai deposan dibank syariah berperan sebagai investor murni yang menanggung aspek sharing risk dan return dari bank. Dengan demikian deposan bukanlah lander atau pembiayaanor bagi bank seperti halnya pada bank konvensional. Secara garis besar mudharabah terbagi menjadi dua jenis, yaitu: Mudharabah Muthlaqah Dalam prinsip hal utama yang menjadi cirinya adalah shahibul maal tidak memberikan batasan batasan atas dan a yang diinvestasikan atau dengan kata lain, mudhorobah diberi wewenang penuh mengelola tanpa terikat waktu, tempat, jenis, usaha, dan jenis pelayanannya. Aplikasi perbankan yang sesuai dengan akad ini adalah tabungan dan deposito berjangka, Mudharabah Muqayyadah. Pada jenis akad ini, shahibul maal memberikan batasan atas dana yang diinvestasikannya. Mudharib hanyabisa mengelola dana tersebut sesuai dengan batasan jenisusaha, tempat, dan waktu tertentu saja. Aplikasinya dalam perbankan adalah special investment based on restricted mudharabah. Model ini dirasa sangat cocok pada saat krisisdimana sektor perbankan mengalami kerugian meyeluruh. Dengan special investmen, investor tertentu tidak perlu menanggung over head bank yang terlalu besar karena seluruh dananya masuk ke proyek khusus dengan returndan cost yang dihitung khusus pula (Andrianto, 2019). Dari latar belakang tersebut, penulis sangat tertarik untuk mengetahui bagaimana penerapan akad Mudharabah pada produk tabungan berjangka yang diterapkan di BMT Tanjung dan Analisis produk tabungan berjangka di BMT Tanjung, sehingga penulis akanmengambil judul tugas akhir "Analisis Produk Tabungan Mudharabah Berjangka Di Bmt Tanjung”, 


\section{METODE PENELITIAN}

Dalam hal ini penulis menggunakan penelitian kualitatif yaitu penelitian yang ditujukan untuk mendiskripsikan dan menganalisis fenomena, peristiwa, aktivitassosial, sikap dan pemikiran orang secara individu maupun secara kelompok. (Ghony, 2003)Penelitian kualitatif ini dilakukan dengan metode wawancara dan obeservasi secara langsung, kemudian data akan dianalisis secara mendetail. Data yang dikumpulkan bersifat asli atau alamiah (natural setting) sesuai dengan data data yang telah didapatkan dilapangan, penelitian ini juga dapat memunculkan teori dan kondep baru.

\section{HASIL DAN PEMBAHASAN}

\section{A.Tabungan Mudharabah Berjangka}

Pengertian tabungan berjangka (Deposito)Pada dasarnya, sistem penghimpunan dana pada bank syariah menurut sumbernya meliputi: modal, titipan, dan investasi.Deposito pada bank syariah termasuk sumber dana yang berasal dari investasi masyarakat yang dihimpun berdasarkan akad mudharabah, maka deposito dibank syariah disebut dengan deposito mudharabah. (Antonio, 2000). Jangka waktu deposito mudharabah berkisar waktu tertentu. Dalam transaksi deposito mudharabah, bank syariah bertindak sebagai mudharib(pengelola dana), sedangkan nasabah bertindak sebagai shahibul maal (pemilikdana). Dalam kapasitasnya sebagai mudharib, bank syariah dapat melakukan berbagai macam usaha yang tidak bertentangan dengan prinsip syariah serta mengembangkannnya, termasuk melakukan akad mudharabah dengan pihak ketiga.

Mudharabah adalah bahasa yang digunakan oleh penduduk Irak, sedangkan hijaz menyebut mudharabah dengan istilah muqaradhah atau qiradh. Sedangkan dalam perkembangan lebih lanjut istilah mudharabah dan qiradh juga mengacu pada makna yang sama. (Huda, 2011) Menurut bahasa mudharabah atau qiradh yang berasal darial-qardhu, berarti al-qath'u (potongan) karena

pemilik memotong sebagian hartanya untuk diperdagangkan dan memperoleh sebagian keunt ungannya. (Suhendi, 2010) Mudharabah berasal dari kata dharb berarti memukul atau berjalan. Pengertian memukul

atau berjalan ini lebih tepatnya adalah proses seseorang memukulkan kakinya dalam menjala nkan usaha. Menurut istilah mudharabah adalah akad kerja sama usaha antara dua pihak dimana pihak pertama (shahibul mal) menyediakan seluruh modal, sedangkan pihak lainnya menjadi pengelola. Keuntungan usaha secara mudharabah dibagi menurut kesepakatan. (Ascarya, 2008) Sedagkan apabila rugi ditanggung oleh pihak modal selama kerugian itu di akibatkan karena kecurangan atau kelalaian si pengelola, sipengelola harus bertanggung jawab atas kerugian tersebut. (Antonio, 2000)

\section{A. Jenis-jenis akad mudharabah}

\section{Mudharabah muthlaqah}

Transaksi mudharabah mutlaqah adalah akad mudorobah tanpa batas,bentuk kerjasama antara shahibul mal dan mudharib yang cakupannya sangat luas dan tidak dibatasi oleh spesifikasi jenis usaha, waktu, dandaerah bisnis. Dalam mudharabah muthlaqah tidak ada 
pembatasan bagi bank dalam menggunakan dana yang dihimpun (Ifham, 2015). Dalam jenis akad ini dikembangkan produk tabungan dan deposito sehingga terdapat dua jenis penghimpunan dana yaitu: tabungan mudharabah dan deposito mudhorobah. (Ifham, 2015)Adapunketentuan dan karakter tabungan mudharabah dan deposito mudharabah yaitu

\section{A. Ketentuan tabungan mudharabah}

a. Dalam transaksi ini nasabah bertindak sebagai shahibul mal atau pemilik dana dan bank bertindak sebagai mudharib atau pengelola dana.

b. Dalam kapasitasnya sebagai mudharib, bank dapat melakukan berbagai macam usaha yang tidak bertentangan dengan prinsip syariah dan mengembangkannya termasuk didalamnya mudharabah dengan pihak lain.

c. Modal harus dinyatakan dengan jumlah dalam bentuk tunai dan bukan piutang.

d. Pembagian keuntungan harus dinyatakan dalam bentuk nisbah dan di untungkan dalam akad pembukaan rekening.

e. Bank sebagai mudharib menutup biaya operasional deposito dengan menggunakan nisbah keuntungan yang menjadi haknya.

f. Bank tidak diperkenankan untuk mengurangi nisbah keuntungan nasabah tanpa persetujuan yang bersangkutan. (Ali, 2008)

\section{B.Karakteristik dan ketentuan umum deposito mudharabah}

Adapun karakteristik dan ketentuan umum dalam deposito mudharabah adalah sebagai berikut:

a) Bank wajib memberitahukan kepada pemilik dana mengenai nisbah dan tata cara pemberitahuan keuntungan atau pembagian keuntungan secara resiko yang ditimbulkan dari penyimpanan dana, yang dicantumkan di awal akad.

b) Pada deposito mudharabah, wajib diberikan sertifikat atau tanda penyimpanan deposito kepada deposan.

c) Deposito mudharabah hanya dapat dicairkan sesuai dengan jangka waktu yang telah disepakati. Deposito yang diperpanjang setelah jatuh tempo akan diperlakukan sama seperti deposito baru, tetapi bila pada akad sudah dicantumkan perpanjangan otomatis, maka tidak perlu dibuat akad baru.

d) Modal dinyatakan dengan jumlahya dalam bentuk tunai dan bukan piutang.

e) Ketentuan-ketentuan lain yang berkaitan dengan deposito tetap berlaku sepanjang tidak bertentangan dengan prinsip syariah.

\section{Mudharabah muqayyadah}

Transaksi mudharabah muqayyadah adalah akad mudharabah dengan pembatasan (restriced investment account-RIA) (Ali, 2008)shahibulmaalmemberikan batasan atas dana yan g di investasikannya, mudharib biasannya hanya bisa mengelola dana tersebut sesuai dengan batasan yang diberikan oleh shahibul maal. Misalnya hanya untuk jenis tertentu saja, tempat tertentu dan lain-lain.Ada dua jenis usaha mudharabah muqayyadah yaitu:

\section{a) Mudharabah muqayyadah on balance sheet}


Mudharabah Jenis ini merupakan dimana pemilik dana dapat menetapkan syarat-syarat tertentu yang harus dipatuhi oleh bank. Nasabah mensyaratkan dananya hanya boleh digunakan untuk nasabah dalam sektor tertentu saja, misalnya: pertanian,manufaktur, pertambangan dan properti. Berdasarkan sektor dapat juga mensyaratkan berdasarkan jenis akad yang digunakan, misalnya hanya boleh digunakan berdasarkan akad penjualan saja, akad penyewaan saja, atau kerjasama usaha saja.

Karakter jenis simpanan ini ialah:

a. Pemilik dana wajib menetapkan syarat syarat tertentu yang harus diikuti bank dan wajib membuat akad yang mengatur persyaratan penyaluran dana simpanan khusus

b. Bank wajib memberitahukan kepada pemilik dana mengenai nisbah dan tata cara pemberitahuan keuntungan atau pembagian serata reiko yang dapat ditimbulkan dari penyimpanan dana.

c. Sebagai tanda bukti menerbitkan bukti simpanan khusus

d. Untuk deposito mudharanah, bank wajib memberikan sertifikatatau tanda penyimpanan depposito kepada deposan. (Ali, 2008)

\section{b) Mudharabah muqayyadah off balance sheet}

Mudharabah ini merupakan penyaluran dana langsung kepada pelaksana usahanya, dimana bank bertindak sebagai perantara(arrange) yang mempertemukan antara pemilik dana dengan pemilikusaha. Sedangkan bagihasilnya hanya melibatkan nasabah dan pelaksana usahasaja. (Karim, 2011)

Adapun yang dimaksud secara khususdengan deposito mudharabah atau yang disebut dengan deposito investasi mudharabah, merupakan investasi melalui tabungan pihak ke tiga (perseorangan badanhukum), yang penarikannya hanya dapat dilakukan dengan jangka waktu tertentu saat jatuh tempo dengan mendapatkan bagi hasil. (Karim, 2011)Adapun syarat dan rukun mudharabah yaitu sebagai berikut: (Nawawi, 2012)

a. Pemilik modal dan pengelola keduanya harus mampu bertindak sebagai pemilik modal serta cakap dalam hukum.

b. Ucapan serah terima kedua belah pihak untuk menunjukkan kemauan mereka dan terdapat kejelasan tujuan kemauan mereka dalam melakukan sebuah kontrak atautransaksi.

c. Modal adalah sejumlah uang yang diberikan oleh pemilik modal (shahibul mal) kepada pengelola (mudharib) untuk tujuan investasi dalam akad mudharabah. Modal disyaratkan harus diketahui jumlahnya, jenisnya (mata uang) dan modal harus disetor tunai kepada mudharib.

d. Keuntungan adalah jumlah yang didapat sebagai kelebihan dari modal, pembagian keuntungan harus jelas dan sesuai nisbah yang disepakati. Keuntungan adalah tujuan akhir dari mudharabhah.

e. Pekerjaan atau usaha perdagangan merupakan konstribusi pengelola dalam kontrak mudharabah yang disediakan oleh pemilik modal. Pekerjaan dalam kaitan ini 
berhubungan dengan manajemen kontrak mudharabah dan ketentuan-ketentuan yang telah ditetapkan oleh kedua belah pihak dalam transaksi.

Akad mudharabah memilikibeberapa rukun yang telah ditentukan guna mencapai keabsahannya yaitu: (Susanto \& Umam, 2013)
a. Pemilik dana (shahibul mal)
b. Pengelola (mudharib)
c.Ucapan serah terima (shiqhat ijab dan qobul)
d. Modal (ra'sul mal)
e. Pekerjaan dan keuntungan.

Peranan KSPPS sebagai salah satu lembaga keuangan tidak pernah lepas dari simpan pinjam dan pembiayaan kepada masyarakat kecil atau nasabah sesuai produk dan akad yang telah ditetapkan. Salah satu produk yang terdapat pada KSPPS yaitu produk mudharabah. Pada produk mudharabah terdapat simpanan mudharabah dan pembiayaan mudharabah. Simpanan mudharabah hanyalah tabungan setoran dan penarikan yang dapat dilakukan kapan saja yang dijalankan berdasarkan akad mudharabah. Misalnya pada Koperasi Simpan Pinjam dan Pembiayaan Syariah (KSPPS) BMT Tanjung.

Dalam KSPPS pembiayaan yang sering digunakan dalam lembaga keuangan syariah diantaranya menggunakan sistem pembiayaan yakni guna memperlancar roda perekonomian ummat, sebab dianggap mampu menekan terjadinya inflasi karena tidak adanya ketetapan bunga yang harus dibayarkan $\backslash k e$ bank, selain itu juga dapat merubah haluan kaum muslimin dalam setiap transaksi perdagangan dan keuangan yang sejalan dengan ajaran syariah Islam. (Ernawati, 2012)

Pembiayaan mudharabah adalah sebuah bentuk penolakan terhadap sistem bunga yang diterapkan oleh bank konvensional dalam mencarikeuntungan, karena itu pelarangan bunga di tinjau dari ajaran Islam merupakan perbuatan riba yang diharamkan dalam al-Quran, sebab larangan riba tersebut bukanlah meringankan beban orang yang dibantu yang dalam halini adalah nasabah, melainkan merupakan tindakan yang dapat memperalat dan memakan harta orang lain. Sejauh ini melihat bahwa bunga bankmerupakan riba yang harus dihindari, sedangkan prinsip bagi hasil merupakan prinsip yang sesuai dengan Islam. Mudharabah sebagai sebuah kegiatan kerjasama ekonomi antara dua pihak mempunyai beberapa ketentuan ketentuan yang harus dipenuhi dalam rangka mengikat jalinan kerjasama tersebut dalam kerangka hukum. (Muhammad, 2005)

\section{Produk Tabungan Mudharabah Berjangka Di BMT Tanjung}

\section{Tabungan Mudharabah}


Tabungan Mudharabah merupakan tabungan atau calon anggota sebagai pemilik dana yang penyetorannya bisa dilakukan dikantor ataupun dirumah dan ditempat usaha.

Keuntungan dari tabungan mudharabah berjangka ini anggota bisa mengambil atau menyetor dana sewaktu-waktu dijam layanan.Untuk penyetorandana pertama minimal Rp. 20.000,setelah setoran awal, penyetoranselanjutnya bisa sesuai dengan keinginananggota.

a. Persyaratan Tabungan Mudharabah Berjangka:

1) Mengisi formulir aplikasipermohonan SimpananAmanah

2) Melampirkan foto copy KTP(yang berlaku)

3) Setoran pertama minimal Rp.20.000,-

4) Setoran selanjutnya minimalRp. 5000,-

b. Fasilitas Tabungan Mudharabah Berjangka:

1. Dapat melakukan penyetoran dan penarikan sewaktu-waktu pada jam kerja dikantor Koprasi Simpan Pinjam Pembiayaan Syariah (KSPPS) BMT Tanjung

2. Dapat melakukan penyetoran dan penarikan dirumah, warung atau pasar. c. Keuntungan Tabungan Mudharabah Berjangka

1) .Dikelola secara syariah, bebasriba, mententramkan danmenentangkan hati.

2). Memperoleh bagi hasil yangmenarik dan kompetitif setiapbulan yang akan ditambah padasaldo Simpanan.

3). Gratis Biaya Administrasi(saldo simpanan tidak akanberkurang).

\section{Tabungan Berkala}

Tabungan herkala merupakan salahsatu produk tabungan di KSPPS BMT

Tanjung.Tabungan berkala hampir sama dengan tabungan mudharabh berjangka, akan tetapi dalampengambilannya hanya bisa dilakukanpada waktu tertentu sesuai dengan produkataupun akad yang diambil. Dalamsimpanan berkala ini ada system bagihasil antara anggata dan BMT yaknisebesar 40\%. Tabungan berkala terdiridari beberapa produk:.

a. Tabungan pendidikanMerupakan tabungan anggota atau calon anggota untuk persiapan pendidikan. tabungan ini bisa diambil pada akhir tahun atau pada saat ajaran baru.

b. Tabungan Qurban atau Aqiqah Merupakan simpanan yang dilakukan oleh anggota untuk persiapan qurban dan aqiqah yang penyetoran dananya bisa dilakukan setiap saat dijam kantor. Sedangkan tabungan ini hanya bisa diambil pada saat hari raya Qurban dan Aqiqah.

c. Tabungan Idul Fitri Merupakan tabungan yang dilakukan oleh anggota untuk persiapan hari raya Idul Fitri yang penyetoran dananya bisa dilakukan setiap saat dijam kantor namun tabungan ini hanya bisa diambil pada saat Hari Raya Idul Fitri yang bisa diambil pada saat bulan Ramadhan.

d. Tabungan Haji Merupakan tabungan yang dikhususkan bagi umat islam yang akan menjalankan ibadah haji atau umrah. Dengan setoran minimal Rp.10.000,- setiap bulan 
dan mendapatkan bagi hasil sebesar 40\%. Jika kekurangan dana, BMT bisa menatanginya dengan cara mengajukan permohonan terlebih dahulu.

e. Tabungan Menikah Merupakan tabungan anggota atau calon anggota untuk persiapan pernikahan. Tabungan bisa diambil sesuai jangka waktu yang telah disepakati oleh kedua pihak.

f. Tabungan Religi Merupakan tabungan yang dilakukan para anggota untuk perjalanan Religi atau Ziarah yang nantinya tujuan lokasi, bis, konsumsi, dll akan dikelola oleh panitia atau pihak BMT. Simpanan ini tidak bisa diambil sewaktu- waktu. Hanya bisa diambil ketika pelaksanaan Religi akan dilakukan.

g. Tabungan DirhamMerupakan salah satu produk tabungan unggulan yang banyak diminati oleh para anggota BMT karena banyak keuntungan dan kemudahan. Dengan syarat dan ketentuan penyetoran simpanan dirham ditarget satu bulan Rp.200.000,selama 24 bulan.Pengambilannya hanya bisa dilakukan setelah batas waktu yang ditentukanatau 24 bulan dengan dana terkumpul Rp. 4.800.000,- pada saat pengambilanya akan disertai undian hadiah seperti smartphone, kipas angin, mesin cuci, kulkas, TV, sepeda, kompor dan hadiah utama motor dengan jenis dan merk tidak menentu. Nantinya setiap anggota akan mendapatkan hadiah tersebut yang diundi setiap 8 bulan sekali.

h. Tabungan siumat Merupakan tabungan yang dikukan para nasabah setiap hari dan dengan jumlah uang dan batas waktu pengambilan yang tidak ditentukan.

\section{Tabuangan dirham}

Merupakan salah satu produk simpanan uanggulan yang banyak diamanati oleh para anggota BMT Taanjung karena banyak keuntungan serta kemudahan dengan sayarat dan tetentuan yang telah ada. Ketentuan yang berlaku pada tabungan Dirham atara lain:

a. Jangka waktu periode 24 bulan.

b. Peserta yang lebih dari 2 bulan tidak melakukan setoran baik berturut- turut atau tidak. Maka tidak diperbolehkan mengikuti undian doorpize utama.

c. Peserta yang terlambat atau tidak setor pada bulan yang bersangkutan akan dikenakan biaya $5 \%$ dari besar setoran.

d. Peserta yang mengundurkan diri adalah yang telah 2 bulan atau 2 kali tidak melakukan setoran.

e. Peserta yang berhenti tanpa ada pengganti akan dikenakan biaya administrasi sebesar 50\% dari dana yang sudah disetorkan.

f. Bagi yang sampai pada bulan terakhir belum menyelesaikan setoran tidak diperbolehkan menutup kekurangan, tetapi melakukan setoran rutin sampai tercapai setoran ke 24

\section{Tabungan Mudharabah Berjangka}


Merupakan Tabungan yang digunakan dalam perencanaan suatu usaha. Anggota atau calon anggota yang menyimpan dananya dalam jangka waktu tertentu dan akan diberikan bukti berupa sertifikat. Untuk pembagian keuntungan sesuai dengan kesepakatan yang telah ditetapkan di awal penyimpanan dana.Semakin lama jangka waktunya makasemakin besar bagi hasil yang diperoleh,antara lain jangka waktu 4 bulannisbahnya 42,5\%, jangka 6 bulannisbahnya $45 \%$, jangka 12 bulannisbahnya $48 \%$, dan jangka 24 bulan nisbahnya $60 \%$. Pengambilan si berkahhanya boleh dilakukan ketika waktusudah jatuh tempo. Jika terpaksa diambilsebelum jatuh tempo, maka akan dikenakan denda atau biaya pinaltisebesar $50 \%$ dari dana yang dimasukkan ke BMT.

\section{E. Pengelolaan Tabungan Mudharabah Berjangka Syariah di BMT Tanjung}

Penelitian bahwa BMT Tanjung mengelola produk tabungan berjangka syariah selain menggunakan modal sendiri juga menghimpun dana dari masyarakat dengan menggunakan prinsip mudharabah (bagi hasil) karena yang diterapkan di BMT Tanjung hanya prinsip mudharabah saja. Dalam pengelolaan tabungan berjangka syariah keuntungan disepakati bersama, sedangkan kerugian ini di sebabkan bukan karena kelalaian pengusaha. Akan tetapi jika kerugian tersebut karena kelalaian pengusaha, maka pengusaha berkewajiban menanggung kerugian tersebut.

\section{F. Mekanisme Bagi Hasil Tabungan Berjangka Syariah di BMT Tanjung}

Mekanismebagi hasil tabungan berjangka syariah di BMT Tanjung, adalah sebagai bagi hasil dalam bentuk usaha kerja sama boleh didasarkan pada prinsip bagi untung(Profit Sharing). berikut:

Syarat syarat mekanisme bagi hasil tabungan berjangka di BMT Tanjung sebagai

1. Memiliki dan menyerahkan tandabukti diri, yaitu:

a) WNI: KTP atau SIM

b) WNA: paspor yang dilengkapi dengan kartu izin menetap sementara (KISM) atau kartu izin tetap (KITAP), apabila terdapat perbedaan dengan alamat tinggal tetap dengan yang tertera pada dokumen tersebut di atas, maka calon deposan harus melengkapi informasi tersebut di atas, maka calon deposan harus melengkapi informasi mengenai alamat tetap tersebut.

c) Menyerahkan foto copy legalitas perusahaan yang bentuk hukumnya di atur dengan peraturan-peraturan perundang-undangan (syarat bukan perorangan).

d) Mengisi formulir aplikasi pembukaan rekening dan lanjutan setoran minimal Rp.1.000.000,00.

e) Pencarian deposito sebelum jatuh tempo berakhir dikenakan denda sesuai dengan ketentuan bank.

f) Dalam aplikasi pembukaan tabungan berjanka syariah, nasabah biasanya melihat keun tungan-keuntungan yang ditawarkan akan produk tabungan berjangka syariah tersebut. 


\section{ANALISIS DATA}

Untuk memperoleh data tentang mekanisme bagi hasil tabungan berjangka syariah peneliti melakukan wawancara, (tanya jawab), observasi, dokumentasi dengan pihak BMT Tanjung. Dalam bab ini peneliti akan menganalisis tabungan mudhrabah berjangka, sehingga dapat diperoleh informasi berdasarkan realita yang ada dilapangan. Tujuan ingindicapai dari penelitian ini adalah agarpembaca dapat mengambil hepotesis atas mekanisme bagi hasil tabungan berjangka syaiah yang ada di BMT Tanjung.

\section{A. Analisis Pengelolaan Tabungan Berjangka Syariah di BMT Tanjung.}

Bagi hasil dalam bahasa Inggris dikatakan dengan profit sharing. Profit sharing dalam kamus ekonomi diartikan sebagai pembagian laba. Menurut istilah bagi hasil adalah suatu sistem yang meliputi tata cara pembagian hasil usaha antara penyedia dana dan pengelola dana. Jadi bagi hasil adalah suatu sistem yang digunakan lembaga keuangan syariah dalam memberikan keuntungan kepada shahibul maal dan mundharib sesuai porsi yang telah disepakati oleh kedua pihak di awal akad. Dan pelaksanannya dilakukan denagan cara memberikan hadiah secara langsung akhir tahun seprti kipas angi, kompor, dan sepeda ontel.

\section{B. Analisis Mekanisme Bagi Hasil Tabungan Berjangka Syariah di BMT Tanjung}

Mekanisme bagi hasil tabungan berjangka syariah pada BMT Tanjung banyak para anggota yang menggunakan tabungan berjangka syariah. Tabungan berjangka (Deposito) adalah simpanan yang penarikannya hanya dapatdilakukan pada waktu-waktu tertentumenurut perjanjian antara penyimpan dengan lembaga yang bersangkutan.Sedangkan yang dimaksud deposito syariahadalah deposito yang dijalankan berdasarkan prinsip syariah. Dalam hal ini, Dewan Syariah Nasional MUI telah mengeluarkan fatwa yang menyatakan bahwa depositoyang dibenarkan adalah deposito yangberdasarkan prinsip mudharabah. Adapun yang dimaksud secara khusus dengan deposito mudharabah, merupakan investasi melalui simpanan pihak ke tiga(perseorangan badan hukum), yang penarikannya hanya dapat dilakukan jangka waktu tertentu saat jatuh tempo dengan mendapatkan bagi hasil. Jangka waktu deposito mudharabahberkisar antara 3, 6, 9 dan 12 bulan. Dalam transaksi deposito mudharabah, bank bertindak sebagai mudharib (pengeloladana), sedangkan nasabah bertindak sebagai shahibul mal (pemilik dana). Dalam kapasitasnya sebagai mudharib, bank syariah dapat melakukan berbagai macam usaha yang tidak bertentangan dengan prinsip syariah serta mengembangkannya, termasuk melakukan akad mudharabah dengan pihak ketiga. Sedangkan produktabungan berjanka syariah di BMT Tanjung menggunakan akad mudharabah, yangdirancang sebagai sarana untuk investasibagi masyarakat yang mempunyai dana dan berlebihan dana. Yang merupakan produkinvestasi berjangka, dimana nisbah bagi hasil diberikan setiap bulan dan dapat diambil secara tunai atau ditabung ke rekening 
anggota. Produk deposito mudharabah diBMT Tanjung disediakan dengan beberapa pilihan jangkawaktu dengan nisbah sebagai berikut:
a. Jangka waktu 3 bulan
b. Jangka waktu 6 bulan
c. Jangka waktu 9 bulan
d. Jangka waktu 12 bulan

Nisbah yang diberikan untuk deposandalam produk tabungan berjangka syariahdengan akad mudharabah di BMT Tanjung perbulannya tergantung pada situasi dan

kondisi.

Syarat pembukaan rekening tabungan berjangka syariah pada BMT Tanjung adalah sebagai berikut:

1. Memiliki dan menyerahkantanda bukti diri, yaitu:

a) WNI: KTP atau SIM

b) WNA: paspor yang dilengkapi dengan Kartu Izin Menetap Sementara (KISM) atau kartu izin tetap (KITAP), apabila terdapat perbedaan dengan alamat tinggal tetap dengan yang tertera pada dokumen tersebut di atas, maka calon deposan harus melengkapi informasi tersebut di atas, maka calon deposan harus melengkapi informasi mengenai alamat tetap tersebut.

c) Menyerahkan foto copy legalitas perusahaan yang bentuk hukumnya di atur dengan peraturan-peraturan perundang-undangan (syarat bukan perorangan).

d) Mengisi formulir aplikasi pembukaan rekening dan lanjutan setoran minimal Rp.1.000.000,00.

e) Pencarian deposito sebelum jatuh tempo berakhir dikenakan denda sesuai dengan ketentuan bank.

f) Dalam aplikasi pembukaan tabungan berjanka syariah, nasabah biasanya melihat keuntungankeuntungan yang ditawarkan akan produk tabungan berjangka syariah tersebut.

Anggota bisa menanyakan mengenai hal-hal sebagai berikut:

1) Keamanan menyimpanuang dalam produk tabungan berjangka syariah.

2) Biaya administrasi

3) Keuntungan yang akanditerima

Atas pernyataan tersebut, bagian CostumerService (CS) menjelaskantentang produk tabungan berjangka syariah di BMT Tanjung kepada nasabah bahwa menyimpan uang dikoperasi 
syariah dalam produk simpanan berjangkasyariah aman, karena dijamin oleh LPS, dalam pengelolaan produk tabungan berjangka dikenakan biaya

administrasi bulanan, biaya dikenakan atas bagi hasil yang diterima dengan dipotong pajak jika nominal depositonya lebih dari Rp.7.500.000,00. Serta nantinya nasabah tetapmendapatkan bagi hasil yang sesuai syariah menguntungkan dan kompetitif.

Prosedur tabungan berjangka syariah di BMT Tanjung adalah sebagai berikut:

1. Nasabah datang ke kantor BMT Tanjung, nasabah menyerahkan identitas diri.

2. Nasabah mengisi aplikasi pembukaan rekening tabungan berjangka syariah, diproses oleh pihak BMT Tanjung.

3. Nasabah dikasih tanda bukti berupa warkat.

4. Nasabah diberitahu tentang nisbah bagi hasil dan tata cara pemagian keuntungan.

5. Simpanan berjangka syarah hanya dapat dicairkan sesuai dengan jangka waktu atau diperpanjan secara otomatis (ARO). Namun dalam keadaan mendesak, nasabah di BMT Tanjung dapat mencairkan depositobya sebelum jatuh tempo. Hal ini dikarenakan bagaimanapun dana nasabah yang mereka simpan tetap merupakan dana mereka dimana BMT Tanjung tidak berhak menahan dana tersebut untuk di ambil. Atas hal tersebut BMT Tanjung mengenakan denda atau penalty yang nantinya berpengaruh pada bagi hasil yang telah diterima deposan. Denda atau penalty yang dibebankan kepada nasabah ketika pencairan yang tidak sesuai jatuh tempo akan dipotong $10 \%$ dari nominal deposito, untuk mengurangi resiko di ambil tidak sesuai jangka waktu yang sudah ditetapkan dalam perjanjian.

6. Mekanisme pencairan deposito Nasabah datang kebagian Costumer Service (CS) membawa sertifikat deposito. CS memberikan form penutupan deposito. Form tersebut dapat diisi CS atau nasabah yang bersangkutan. Sertifikat asli diminta beserta FC identitas, nasabah diberi slip penarikan untuk mengambil uangnya ditellar jika di ambil tunai, atau bisa dibawakan oleh marketingnya dan di antar sampai rumah nasabah. Sedangkan untuk deposito yang diperpanjang waktunya harus menganti warkat lama ke warkat baru sesuai waktunya. Karakteristik dan distribusi hasil usaha tabungan berjangka syariah di BMT Tanjung Produk tabungan berjangka syariah BMT Tanjung menggunakan akad mudharabah, yang dirancang sebagai sarana untuk investasi bagi masyarakat yang mempunyai dana. Produk investasi berjangka, dimana nisbah bagi hasil diberikan setiap bulan dan dapat di ambil secara tunai atau di masukkan ke dalam rekening tabungan. Konsep bagi hasil dan penerapannya pada tabungan berjangaka syariah pada bank syariah, salah satu prinsip operasionalnya adalah prinsip bagi hasil, yaitu suatu prinsip yang meliputi tata cara pembagian hasil usaha antara pemodal dengan pengelola modal. Dalam kaitannya dengan penghimpunan dana, pembagian hasil usaha tersebut berarti dilakukan antara bank dengan nasabah penyimpan dana. hasil usaha yang dibagikan kepada nasabah adalah laba usaha bank dalam periode tertentu. 
Metode yang digunakan BMT TANJUNG dalam membagi hasil usahanya adalah sebagai berikut:

A. Bagi hasil mudharabah dapat dilakukan dengan menggunakan dua metode, yaitu bagi laba (profit sharing) atau bagi pendapatan (revenue sharing). Bagi laba dihitung dari pendapatan setelah dikurangi beban yang berkaitan dengan pengelolaan dana mudharabah sendangkan bagi pendapatan, dihitung dari total pendapatan pengelola mudharabah.

B. Jika bank menggunakan metode bagi hasil (profit sharing) dan usaha mengalami kerugian maka seluruh kerugian ditanggung oleh pemilik dana (shahibul mal), kecuali jika ditemukan adanya kelalaian atau kesalahan bank sebagai pengelola dana (mudharib).

Jika bank menggunakan metode bagi pendapatan (revenue sharing), maka pemilik dana (shahibul mal) tidak akan menanggung kerugian, kecuali bank dilikuidasi dengan kondisi realisasi asset bank lebih kecil dari kewajiban.

\section{KESIMPULAN}

Dari penelitian yang berjudul Analisis Produk Tabungan Mudharabah Berjangka Di BMT Tanjung dapat disimpulkan sebagai berikut:

1. Pengelolaan Tabungan mudharabah berjangka syariah pada BMT Tanjung selain menggunakan modal sendiri, juga menghimpun dana dari masyarakat dengan menggunakan prinsip mudharabah (bagi hasil) karena yang diterapkan di BMT Tanjung hanya prinsip mudharabah saja. Sedangkan mudharabah yaitu akad kerja sama dua orang atau lebih, salah satu pihak yang menyediakan modal secara penuh dan pihak lain menjalankan usaha. Pemilik modal disebut shahibul maal, sedangkan pihak BMT disebut mudharib. Antara keduanya terikat dengan kerja sama usaha. Pembagian keuntungan disepakati bersama, sedang kerugian ini disebabkan bukan karena kelalaian pengusaha. Akan tetapi jika kerugian tersebut karena kelalaian pengusaha, maka pengusaha berkewajiban menanggung kerugian tersebut. Semua pengelolaan tabungan berjangka syariah semua tabungannya masuk funding (tabungan atau simpanan). Dimana presentase pengelolaannya harus sesuai denganaturan yang sudah diterapkan, yaitu dari seluruh funding misalnya $70 \%$ harus dipinjamkan, $70 \%$ ini adalah uang funding yang campuran dari uang harian, pasar dan lain-lain, semua itu digabung menjadi satu. Untuk yang 30\% adalah likuiditas yang digunakan untuk ke amanan dan lembaga keuangan. Tabungan merupakan dana yang dipercayakan oleh masyarakat kepada BMT dalam bentuk Tabungan Syariah, Tabungan Qurban, Tabungan Idul Fitri, Tabungan Umrah, Tabungan Walimah, dan Tabugan Aqiqah. Selanjutnya dari dana tersebut dapat disalurkan ke masyarakat dalam bentuk pembiayaan. 
2. Mekanisme bagi hasil tabungan berjangka syariah pada BMT Tanjung banyak para anggota yang menggunakan tabungan berjangka syariah. Simpanan tabungan berjangka (Deposito) adalah tabungan yang penarikannya hanya dapat dilakukan pada waktuwaktu tertentu menurut perjanjian antara penyimpan dengan lembaga yang bersangkutan. Sedangkan yang dimaksud deposito syariah adalah deposito yang dijalankan berdasarkan prinsip syariah. Dalam hal ini, Dewan Syariah Nasional MUI telah mengeluarkan fatwa yang menyatakan bahwa deposito yang dibenarkan adalahdeposito yang berdasarkan prinsip mudharabah.

Produk tabungan di BMT Tanjung terbagi dari beberapa jenis yaitu : tabungan mudhorobah,, tabungan berkala, tabungan dirham dan tabungan mudrorobah berkala.

\section{DAFTAR PUSTAKA}

Andrianto. (2019). Manajemen Bank Syariah (Implementasi Teori dan Praktek). Surabaya: Qiara Media.

Antonio, M. S. (2000). Bank Syariah dari teori ke Praktek. Jakarta: Gema Insani Press. Ascarya. (2008). Akad dan Produk Bank Syariah. Jakarta: Raja Grafindo.

Ernawati, R. (2012). Analisis Akad Pembiayaan Mudharabah pada BMT dalam Meningkatkan Pendapatan Masyarakat.

Ghony, M. D. (2003). Metodologi Penelitian Kualitatif. Jakarta: Ar-Ruzz Media.

Huda, Q. (2011). Fiqih Muamalah. Yogyakarta: Teras.

Ifham, A. (2015). Ini Lho Bank Syariah. Jakarta: Gramedia Pustaka Utama.

Karim, A. (2011). Bank Islam: Analisis Fiqih dan Keuangan. Jakarta: Rajawali Press.

Kasmir. (2005). Bank dan Lembaga Keuangan Lainnya. Jakarta: Raja Grafindo Persada.

Muhammad. (2005). Manajemen Pembiayaan Bank Syariah. Yogyakarta: YKPN.

Muhammad, R. (2004). Manajemen Baitul Maal wa Tamwil. Yogyakarta: UII Press.

Nawawi, I. (2012). Fiqih muamalah klasik dan kontemporer. Bandung: Ghalia Indonesia.

Sudarsono, H. (2003). Bank dan Lembaga Keuangan Syariah Deskripsi dan Ilustrasi. Yogyakarta: Ekonisia.

Suhendi, H. (2010). Fiqih muamalah. Jakarta: Rajawali Press.

Susanto, H., \& Umam, K. (2013). Manajemen Pemasaran Bank Syariah. Bandung: Pustaka Setia. 